\title{
Understanding the purpose of youth justice in New Zealand
}

\author{
Mike Doolan
}

Mike Doolan, ONZM; MSW (Distinction); MANZASW, is former Chief Social Worker of Child Youth and Family Services and led the policy team responsible for the youth justice provisions of the Children, Young Persons and Their Families Act 1989. He is the co-author of books on kinship care and child homicide and has also published in the fields of youth justice, family group conferencing and violence in society.

\section{Abstract}

The administration of justice can become an arid procedural concern when practitioners lose sight of purpose. This article focuses on the purposes of the youth justice provisions of the Children, Young Persons and Their Families Act 1989. After traversing New Zealand's historical responses to children who offend and contrasting the conceptual underpinnings of those approaches with current legislation, the article identifies the three key aims of youth justice reform which took place during the late 1980s - providing due process guarantees; finding alternatives to enmeshing young people and their families in the formal criminal justice system; and promoting culturally respectful processes. The author argues that almost all of the procedures of the legislation link to one or other of these aims and by understanding these linkages, all youth justice practitioners - judges, legal advocates, coordinators, social workers, police and community service providers - can ensure the intentions of the law are not lost in the exigencies of the day-to-day activity. The article concludes by proposing that all youth justice practitioners, in addition to their role-specific functions, have a collective responsibility to ensure the mandate of the law is given effect.

\section{Introduction}

Youth justice is important. It is the legal scheme for responding to instances where children or young persons break the law and is therefore a powerful instrument in reducing chances that young people will develop offending careers into adulthood. It is also the means by which young people who offend can put matters right with the victims of their offending and gain the opportunity to develop in responsible, beneficial and socially acceptable ways.

The Children, Young Persons and Their Families Act 1989 comprehensively reformed the New Zealand response to offending behaviour of children and young persons. As reforming law, it sits in an historical context and knowledge about how the law came to be as it is can aid practitioner commitment and adherence to its key goals and objectives. 


\section{Historical approaches and the welfare model}

Aries (1962) notes that childhood and adolescence, rather than being natural states constant over time and across societies, are constructions that differ according to historical period, social class, ethnicity and societal values. If childhood is itself an adult construct, it is not surprising that child law, policy and practice are primarily a reflection of adult ideas about childhood.

There appear to be at least three distinct constructions of childhood in the history of New Zealand child welfare leading up to the 1980s (Doolan, 1996):

a. The economic child - before the 1870s. Prior to the middle of the 19th century there was little law distinguishing the needs of children from those of adults. Children of the settler population were economic units employed by families in their drive for survival. The value of children was in their present contribution to family or community well being, rather than any future potential contribution for which they must be prepared and groomed. Children were subject to the same criminal dispositions as adults.

b. The indigent child - from the 1870 s until 1925. Some time after 1870, children began to lose their economic value but in return were gradually being recognised as asset value in society, at least by reformers spurred into providing for needy and deprived children made visible by increasing urbanisation in the colony. Law and practice showed a strong rescue mentality. Separate legal provisions for children emerged for the first time. The primary goal of charitable and state activity was to remove children from unsavoury or dangerous family environments and provide them with rigorous training and moral programming that would equip them for productive, morally correct, adult lives. Residential institutions and later, 'Boarding Out' from Industrial Schools, ${ }^{1}$ formed the basis of government social services for children in 19th century New Zealand. Industrial schools had powers to hold children until they were 21 years of age, and to educate and train them for working life. Children could be held for being destitute or homeless, neglected or maltreated, living in undesirable surroundings or with unsavoury companions, being uncontrollable or mischievous, or for committing offences (Dalley, 1998). The services that did exist were primarily a response to European poverty. The requirement for them predated Maori urbanisation and during this period, it would seem that traditional models of care for Maori remained relatively intact (DSW, 1988, appendix 1; Dalley, 1998).

c. The state child - from 1925 until the 1980s. The first comprehensive law relating to children's needs and deeds was the Child Welfare Act 1925 and this was to dominate practice for the next 50 years. The Act established a separate court for children, emphasised the primacy of fostering over institutionalisation, introduced state monitoring of all ex-nuptial births and formulated regulations to govern the employment of children in street trading and entertainment. This Act and its successor, the Children and Young Persons Act 1974, cemented the role and primacy of the state in ensuring child welfare. In effect, when parents failed, the State stepped in, the law giving no significant encouragement or avenue for extended family involvement. In an era characterised by the theories of Freud, Jung and Erickson, professional activity was devoted to seeking out or determining the antecedents of delin-

Boarding Out was a precursor to the emphasis on foster care, which was to emerge in a later period. 
quency or indigence in the belief that knowledge of the causes of such problems would enable curative action to be taken. 'Problem children' were viewed as products of detrimental environments, which were turning them into anti-social perpetrators. Law and policies responding to this construct of childhood resulted in large-scale alienation of children from 'unsuitable' families, high rates of state care, fostering and institutionalisation and an active adoption regime operating in the country. New Zealand's population almost doubled in the 20 years following the Second World War, and this period also saw the beginnings of what were to become mass movements of Maori populations off traditional tribal areas and rural farmlands and into cities. The work of statutory children's services expanded at an enormous rate and for the first time Maori children began to feature and rapidly made up a disproportionate number of the cases (Dalley, 1998). A system of professional practice that had been designed to respond to the needs of settler families and their children - a system based on what were regarded as the progressive systems operating in the United Kingdom and the United States from the early years of the 20th century - was applied to this new intake of client families. There was no adjustment of method that recognised the change in clientele that had occurred. As a consequence, professionals presided over the alienation of many Maori children from their whanau, hapu, iwi and their hereditary rights 'in their interests and for their own good'.

A number of themes emerged during the 1980s that saw a changing construct of childhood beginning to emerge. The 1979 United Nations Year of the Child established child advocacy and child rights on the country's political agenda. The professional method that dominated practice throughout the century suffered a severe blow in 1982 when the Human Rights Commission of New Zealand found the state department responsible for child welfare in breach of international covenants, particularly in relation to its residential programmes and its treatment of Maori. There were new and more determined efforts by Maori to secure self-determination in a mono-cultural legal system regarded as discriminatory and making little allowance for differences in customs, values and beliefs. ${ }^{2}$ Across the community, in both economic and social arenas, there developed a growing rejection of the paternalism of the state. This had expression in the social services sector in an increasing challenge to the power of medical, legal, educational and welfare professionals and a call for more professional accountability and openness of communication, including more equal status for clients and patients in their relationships with professionals. In relation to young people involved with the state department because of offending behaviour, nothing seemed to be working well. The expected outcome of happy, productive, morally correct lives as a result of state intervention was significantly under-achieved. Costly residential and therapeutic programmes that congregated the troubled and troublesome emerged as part of the problem rather than part of the solution (Doolan, 1990; Doolan, 2003). Welfare objectives had, it was claimed, become the justification for increasing intrusion into the lives of children and their families without noticeable benefit (Watt, 2003). There was a growing recognition that children who had been alienated from their families and their cultures had suffered a disservice and that families needed to be more centrally involved both in finding solutions and putting them into effect. The welfare approach came to be regarded as fundamentally unjust and ineffective both in its processes and in its programmes:

2 Analysis by the Auckland Committee on Racism and Discrimination (ACORD) in the late 1970s, cited in Doolan, 1988, p. 3, demonstrated that Maori and Pacific Nations young people were more likely to be arrested, more likely to be prosecuted and more likely to be incarcerated, than European young people committing the same offences. 
Traditional welfare perceptions categorising the offending child as being mis-guided (or misparented) and thus in need of help and assistance foster (it is claimed) paternalistic procedures characterised by informality and broad discretion in courts and in helping and correctional services alike. The philosophy underlying approaches to the young offender permits sweeping intervention in a manner increasingly challenged as contrary to contemporary values of least possible interference with freedom and rights of due process. In short, high custody and care rates for young offenders are seen to be the product of 'too much welfare and not enough justice' (Doolan, 1988, p. 1).

\section{The contemporary construct of childhood and adolescence}

The construct of childhood underpinning the Children, Young Persons and Their Families Act 1989 perceives children and young persons as having rights and responsibilities. The child is neither subservient to, nor autonomous from, the family, but rather the child and the family - now conceived more broadly as all those connected to the child by kinship or relationships of significance - are centrally and eternally engaged with one another. The interests of the child or young person who offends are no longer paramount - rather their interests must be balanced with those of their families, their victims and the wider community. The role of the state is defender and supporter of kin networks in exercising their responsibilities of parenting and nurturing children (Cockburn, 1994) and assisting them to find solutions when things go wrong. Where the state does intervene, its does so in ways that strengthen the relationship between a child and its family, and strengthen the family's capacity to manage and care for the child. Children and young persons are to be held accountable for acting contrary to law, but because of their age and immaturity they are entitled to special protections in that process.

\section{The Children, Young Persons and Their Families Act}

Three principal drivers emerged for reform of the youth justice system. Almost all the youth justice provisions of the Children, Young Persons and Their Families Act can be traced to one of these reform imperatives.

1. The need for Due Process guarantees. Social work and criminological literature of the 1980s (Stewart \& Tutt, 1987; Miller \& Giller, 1987; Parker, Jarvis \& Summers, 1987; Morris, Giller, Szwed \& Geach, 1980) challenged commonly held perceptions about the antecedents and causes of offending by young people and the common set of practices and procedures employed with those facing criminal charges and those who were in need of care, protection or control. While the New Zealand Children and Young Persons' Court exercised both criminal and civil jurisdiction, in practice there was a blurring of the two. Sources argued that this blurring led to criminal charges being laid in an effort to address issues of care instability or welfare need and resulted in young people being 'sentenced to welfare' through dispositions such as indeterminate and non-specific guardianship or supervision orders. There was a concern that courts dealing with young people who offend should guard procedural guarantees in respect of guilt or innocence and that where sanctions were applied, ensure these were proportional in relation to those applying to adults. Thus, children and young persons should be subject to the same standards of evidence and proof of offending as adults, but that sanctions applicable to them should recognise their age and immaturity. In particular, no child or young person was to suffer a restriction of freedom that would not be permitted or used for adult offenders committing similar 
offences. In addition, in the 1980s courts were challenging and dismissing prosecutions against children and young persons where enforcement authorities had appeared not to apply basic due process guarantees to the processes of their arrest and questioning. New Zealand youth justice law reflects these concepts in the following provisions:

- A Youth Court of purely criminal jurisdiction;

- A definition of the rights of a child or young person when questioned, charged with an offence or arrested;

- Limitations on police powers of arrest;

- The principle that criminal proceedings should not be instituted against a child or young person in order to provide any assistance or services needed to advance the welfare of the child or young person or his or her family;

- Provision for the appointment of a Youth Advocate for any child or young person appearing before the Youth Court;

- Youth Court orders that are specific and determinate and are appropriate to a child or young person's sense of time.

2. Accountability for offending through means other than prosecution. Literature of the period emphasised the importance of minimising the involvement of children and young persons with the formal criminal justice system, which had limited options for responding and often resulted in the congregation of problematic young people in programmes that appeared to make things worse rather than better, because of the associations they formed and the tendency for them to develop identification with a delinquent sub-culture. This may be explained, in part, by labelling theory - formal involvement triggers a process whereby young people begin to identify themselves as criminals, and are also labelled criminals by others, all of which helps to influence future decision to offend (Doolan, 1990). Young people are known to misconstrue much of what happens around them in formal court procedures. The formal system was also seen as insulating the young people from the impact of their offending behaviour on victims and their own families and inhibiting an acceptance of personal responsibility by young people in acknowledging their offending and in putting matters right. There developed, therefore, an imperative to limit involvement with the formal system where this was possible, by an emphasis on means of dealing with the matter other than by prosecution, and by negating or lessening opportunities for young people to develop negative self-concepts. Rather, the goal was to manage young people who offend in the context of their families, rather than in the context of other young people who are offending. New Zealand youth justice law reflects these concepts in the following provisions:

- An object of the Act, that children and young persons are held accountable and encouraged to accept responsibility for their behaviour and dealt with in ways that help them develop as responsible citizens;

- The principle that, unless the public interest requires otherwise, criminal proceedings should not be instituted against a child or a young person if there is an alternative means of dealing with the matter;

- The principle that measures taken should strengthen the family group of the child or young person and foster families' own means of dealing with the offending behaviour;

- The provision for police to issue warnings and formal cautions; 
- The introduction of the family group conference as a higher-level diversion mechanism where enforcement authorities intend to charge the child or young person with an offence;

- The requirement that the Youth Court direct a family group conference be held where a young person is arrested and on advice intends not to contest the facts;

- Strict timeframes for speedy action if a child or young person is in custody;

- The requirement that, where a charge is proved before the Youth Court, the court direct a family group conference be held to advise how it might deal with the matter;

- The entitlement of victims of offences and their support persons to attend family group conferences;

- The provision that courts take steps to limit the congregation of young people who have offended, and their families, on court premises;

- The principle that age is a mitigating factor in determining whether a sanction is required and the nature of any sanction;

- The principle that children and young persons should be kept in the community, consonant with the need for public safety;

- Limitations of the use of custody by police and the Court;

- The provision for Supervision with Activity orders as an alternative to Supervision with Residence.

3. Culturally respectful processes. The 1980s saw a growth in Maori advocacy for increased involvement in decision-making in respect of Maori children. The Human Rights Commission report (HRC, 1982) graphically portrayed institutional and professional biases that created negative impacts for Maori. The establishment of the Maatua Whangai programme that followed was an attempt by central government departments of Justice and Social Welfare to return children and young persons to the care of their whanau, hapu oriwi. While not totally successful in that respect, Maatua Whangai did herald new ways of working with Maori family and social systems, and Maori staff, in particular, began to feel empowered to work in culturally consistent ways within the statutory agencies. In challenging the Department of Social Welfare about inherently racist practices that had become institutionalised over time, a group of women staff (DSW, 1985) was instrumental in forcing the Department to investigate and assess its practices. The Ministerial Advisory Committee on a Maori Perspective for the Department of Social Welfare was appointed in 1985 and this Committee reported first orally that same year, to the Right Honourable Ann Hercus at the national hui at Waiwhetu marae and later in the publication Puao-Te-Ata-Tu (Day Break) (DSW, July, 1986) (Nash, 1998, p. 253). This report recounted the difficulties and injustices created when the dominant culture dominated decision-making processes about Maori children and families with little regard to the values, customs and beliefs of Maori. Maori calls for greater levels of self-determination in matters relating to their children led to the formulation of a decision-making construct known as the family group conference as the central decision-making method to be used whenever there was a risk of the use of coercive powers by the state. By means of the family group conference, Maori, and indeed peoples of all cultures and ethnic groups, can ensure culturally appropriate processes were employed in reaching decisions about responding to the needs or deeds of their young people. The family group conference positions family groups (those wider family networks within which households are nested) to take leadership in working with the state's professionals to resolve concerns and formulate plans about children and 
young persons coming to notice. The Act emphasises the importance of maintaining and strengthening relationships between young people and their families and resolving matters within the context of family systems wherever possible. The family group conference is the mechanism that gives expression to those goals. New Zealand youth justice law reflects these concepts in the following provisions:

- The requirement that a family group conference be held when critical decisions are required in relation to a child and young person;

- The right of whanau, hapu, iwi and family groups to deliberate in private in the course of a family group conference;

- The expectation that professionals and state agencies will follow the lead of family groups in making decisions and plans about children and young persons, where these are consistent with the principles of the Act itself;

- The requirement for courts to consider, when an information has been laid against a young person, any decision, recommendation or plan of a family group conference;

- The privileged nature of the proceedings of a family group conference.

\section{Practitioner mandate}

There are a number of key 'actors' in the administration of the youth justice system, most notably:judges; police; legal advocates; coordinators; social workers; and community service providers. Each has a specific role to play in giving effect to the purposes of the Children, Young Persons and Their Families Act, but further than that, they are collectively responsible for achieving the implicit goal of the Act: assisting young people to forgo a life of crime and to become, instead, good citizens, with all the improvements in life outcomes such a transition can provide. All, then, are responsible for all of the following:

1. Ensuring children and young persons are held accountable, and encouraged to accept responsibility, for their offending behaviour.

2. Promoting ways whereby children and young persons might repair the harm they have caused.

3. Ensuring that the needs of communities for appropriate protection are recognised in any measures taken.

4. Ensuring that a child or young person's family, whanau, hapu, iwi and family group have effective participation in the making of decisions and ensuring that regard is paid to their views.

5. Ensuring that consideration and due weight is given to the wishes of a child or young person in any measures taken, and that decisions affecting a child or young person should be made and implemented in a timeframe appropriate to their sense of time.

6. Ensuring that professional activity, and any measures taken, focus on strengthening and maintaining the relationship between a child and young person and their family, whanau, hapu, iwi and family group.

7. Developing, and giving effect to, plans that allow children and young persons to develop in responsible, beneficial and socially acceptable ways, linking them and their families to programmes and services that address unsatisfactory life conditions.

8. Working to maintain children and young persons in the community as a high priority, reducing the need for, and the use of, custodial provisions.

9. Employing the Care and Protection provisions of the Children, Young Persons and Their 
Families Act 1989 where a compulsion to undertake treatment or therapy is thought necessary.

10. Working to develop strategies that address levels of offending in communities.

\section{References}

Aries, P. (1962). Centuries of childhood: A social history of the family. New York: Vintage Books.

Cockburn, G. (1994). The Children, Young Persons and Their Families Act 1989: Past, present and future. In R. Munford \& M. Nash (Eds.) Social work in action, pp. 85-103. Palmerston North: Dunmore Press.

Dalley, B. (1998). Family matters: Child welfare in 20th century NZ. Auckland: University Press.

Doolan. M. (1996). Social constructs of childhood. Address to 'Children and the Law' Seminar, 20 September. Wellington: NZ Law Society.

Doolan, M. (1993). Youth justice: Legislation and practice. In B. Brown \& F. McElrea (Eds). The Youth Court in New Zealand: A new model of justice. Legal Research Foundation, Publication No 34.

Doolan, M. (1990). Youth justice reform in New Zealand. Community Alternatives, 2(1), 77-90.

Doolan, M. (1988). From welfare to justice: Towards new social work practice with young offenders. Wellington: Department of Social Welfare.

DSW. (1985). Institutional racism in the Department of Social Welfare, Tamaki Makaurau. Report of Women Against Racism Action Group (WARAG Revised). Wellington: Department of Social Welfare.

HRC. (1982). Report of the Human Rights Commission on representations by the Auckland Committee on Racism and Discrimination on Children and Young Persons Homes administered by the Department of Social Welfare. Wellington: Human Rights Commission.

Miller, A. \& Giller, H. (1987).Understanding juvenile justice. London: Croom Helm.

Ministerial Advisory Committee on a Maori Perspective for the Department of Social Welfare. (1986). Puao-Te-Ata-Tu (Day Break). Report of the Ministerial Advisory Committee on a Maori Perspective for the Department of Social Welfare. Wellington: Department of Social Welfare.

Morris, A., Giller, H., Szwed, E., \& Geach, H. (1980). Justice for children. McMillan Press.

Nash, M. (1998). People, policies and practice: Social work education in Aotearoa New Zealand from 1949-95. Unpublished $\mathrm{PhD}$ thesis, Palmerston North: Massey University.

Parker, H., Jarvis, A., \& Summer, M. (1987). Under new orders: The redefinition of social work with young offenders. British Journal of Social Work, 17, 21-43.

Stewart, G. \& Tutt, N. (1987). Children in custody. Aldershot: Avebury.

Watt, E (2003). A history of youth justice in New Zealand. Court in the Act. No.6. Wellington: Department for Courts. 